\title{
Comparing Caddo and Coles Creek Pottery Using Petrographic Analysis
}

Jeffery S. Girard

Northwestern State University of Louisiana

Leslie G. Cecil

Department of Anthropology, Geography, and Sociology

Follow this and additional works at: https://scholarworks.sfasu.edu/ita

Part of the American Material Culture Commons, Archaeological Anthropology Commons, Environmental Studies Commons, Other American Studies Commons, Other Arts and Humanities Commons, Other History of Art, Architecture, and Archaeology Commons, and the United States History Commons

Tell us how this article helped you.

This Article is brought to you for free and open access by the Center for Regional Heritage Research at SFA ScholarWorks. It has been accepted for inclusion in Index of Texas Archaeology: Open Access Gray Literature from the Lone Star State by an authorized editor of SFA ScholarWorks. For more information, please contact cdsscholarworks@sfasu.edu. 
Comparing Caddo and Coles Creek Pottery Using Petrographic Analysis

Creative Commons License

(c) (i) (8)

This work is licensed under a Creative Commons Attribution-NonCommercial 4.0 International License 


\title{
Comparing Caddo and Coles Creek Pottery Using Petrographic Analysis
}

\section{Jeffrey S. Girard and Leslie G. Cecil}

\begin{abstract}
Pottery classified as "Coles Creek Incised" is common both to the earliest Caddo sites along the Red River and to contemporary sites in the Lower Mississippi Valley. Although it often is suggested that Coles Creek pottery from the two regions can be distinguished by differences in paste, no detailed comparative studies have been carried out. An initial attempt to identify variation through the use of petrographic analysis was carried out by comparing 50 samples drawn from sites in northwest and central Louisiana. Although no sharp dichotomy was noted between the regions, the study identified distinctions that support the notion that most Coles Creek pottery was made locally and different technological traditions may be represented.
\end{abstract}

Our study addresses a long-standing issue in Caddo-Lower Mississippi Valley relationships. Pottery classified as Coles Creek Incised is common both to early Caddo sites along the Red River and to contemporary sites in the Lower Mississippi Valley. Although differences in percentages of specific types are present, between the ninth and early eleventh centuries both regions participated in a widespread ceramic decorative tradition. However, it is less clear how alike ceramic technologies were during this period. It has been suggested that much of the Red River Coles Creek pottery has different past characteristics from that to the east and that most probably was made locally. Unfortunately, the hypothesized dissimilarities have only been noted in informal terms and more rigorous technical studies are lacking.

This project is an initial attempt to determine whether significant technological differences are evident between the Coles Creek pottery of the two regions through the use of petrographic analysis. Petrographic analysis allows the identification of minerals present in the clays as well as purposely added inclusions or temper. We are interested in identifying possible distinctions in manufacturing technologies, especially the types and amounts of tempering materials added to the clays. The regions also differ geologically to the extent that, if vessels were manufactured and broken locally, clear variation should be apparent in natural mineral inclusions in the clays. A significant problem, however, is that both regions have complex geologic histories with clays available in multiple contexts. Our understanding of variability at local and regional spatial scales is limited.

We chose samples from two regions (Figure 1). In the Caddo Area, 26 sherds were selected from eight sites, primarily in the Red River drainage of Northwest Louisiana. All of these sites have significant numbers of Coles Creek Incised sherds and likely were occupied sometime in the tenth or early eleventh centuries.

For comparison we selected 24 samples from nine sites located in central Louisiana, a complex region in its fluvial configuration encompassing the Catahoula basin, as well as the lower Ouachita and lower Tensas river basins. We included samples from the Wiley site at Larto Lake, and the well-known Greenhouse site adjacent to the Avoyelles plateau in the lower Red River drainage. In addition, we included one sherd apiece from the Hoover and Bayou Grand Chenier sites located far to the south near the Gulf coast. 


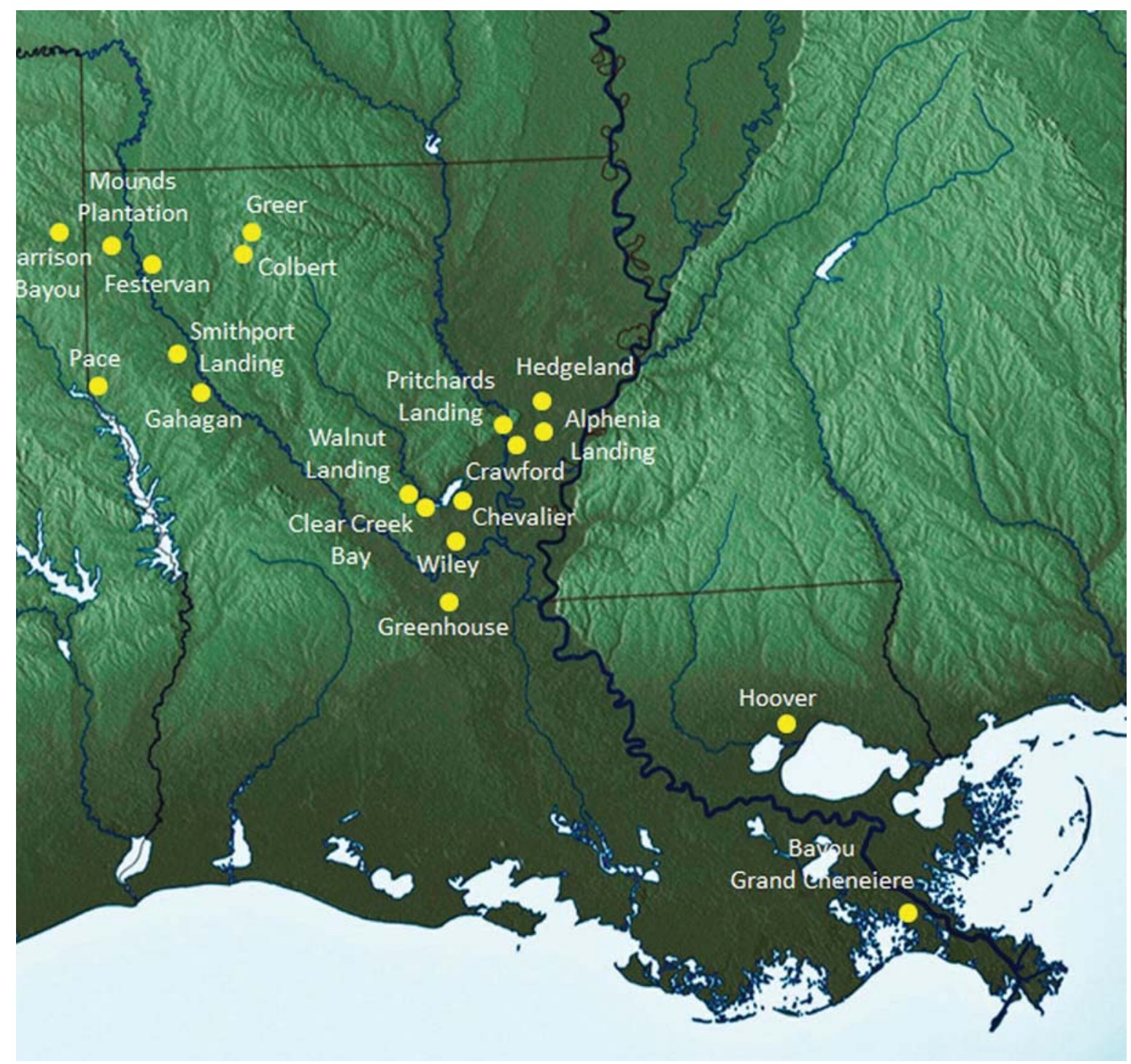

Figure 1. Sites sampled for the petrographic study.

In his report on the Greenhouse Site, James Ford (1951) presented the first detailed definition of the two types we used for this project: Coles Creek Incised and Greenhouse Incised. Philip Phillips (1970) later incorporated Greenhouse Incised into the former type as a variety. For the Caddo Area, Alex Krieger (Newell and Krieger 1949) defined the similar type Davis Incised in his analysis of pottery from the George C. Davis site. In the lower Ouachita River region, Kidder (1990:59) relates var. Coles Creek to the Crawford phase (ca. A.D. 800-900) and var. Greenhouse to the Pritchard's Landing phase (ca. A.D. 900-1050). The few dated contexts where similar pottery dominates in the Caddo Area also fall between A.D. 800 and 1050 (Girard et al. 2014:38-41).

Both types or varieties are present on the sites sampled for this study (Figure 2). We identified var. Coles Creek specimens by either the presence of close-spaced, overhanging horizontal lines or by a row of triangular punctations beneath a field of horizontal lines. The var. Greenhouse sherds have multiple horizontal lines that do not overhang, spaced at intervals of $5 \mathrm{~mm}$ or more. Ford described the paste of Coles Creek Incised as being tempered predominantly by clay with small amounts of sand and occasional small particles of carbonized vegetal matter as well as white stone fragments interpreted as "probably volcanic tufa." He 
described the paste of Greenhouse Incised as being similar, but did not mention sand and noted that "The paste is of somewhat finer texture than is usual for Coles Creek Plain" (Ford 1951:77). Most of the Coles Creek and Greenhouse Incised vessels were simple bowls and jars. Krieger (Newell and Krieger 1949:116-118) noted that Davis Incised consisted mostly of simple bowls, but a few carinated bowls, bottles, and jars were represented as well. He suggested that the type became thicker and coarser through time and contained clay and carbon temper. In the northwest Louisiana collections, Greenhouse or Davis Incised (Coles Creek var. Greenhouse) is more numerous than Coles Creek Incised (Coles Creek var. Coles Creek); the opposite is true in the Lower Mississippi Valley sites, and our samples reflect this-14 of the 26 sherds from the Caddo Area sites are var. Greenhouse; 20 of the 24 samples from the east are var. Coles Creek.
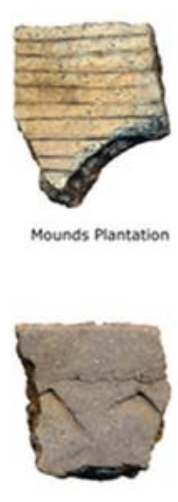

Mounds Plantation

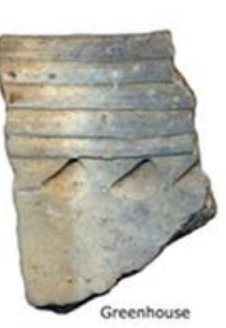

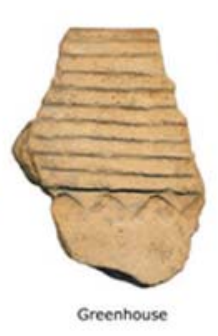

var. Coles Creek

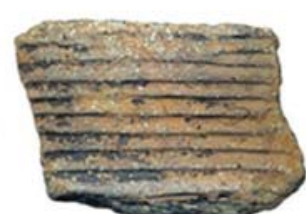

Harrison Bayou

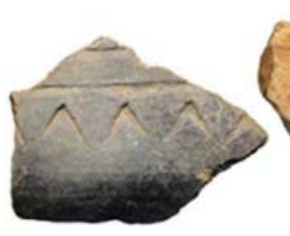

Greer

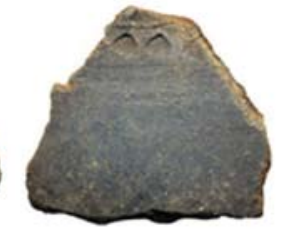

Gahagan
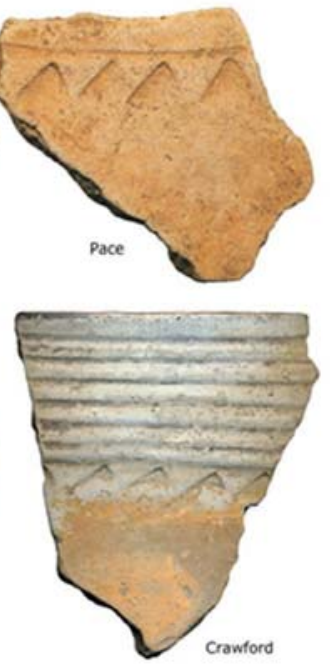

Crawford
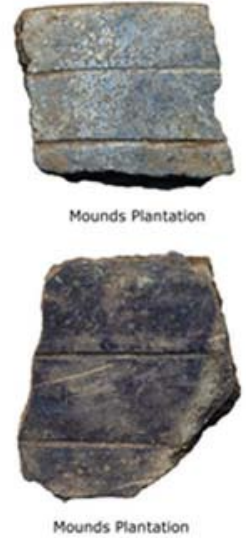

Mounds Plantation

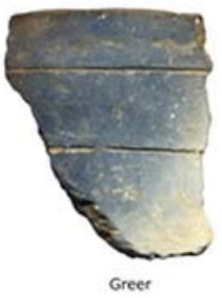

var. Greenhouse

Mounds Plantation

Mounds Plantation
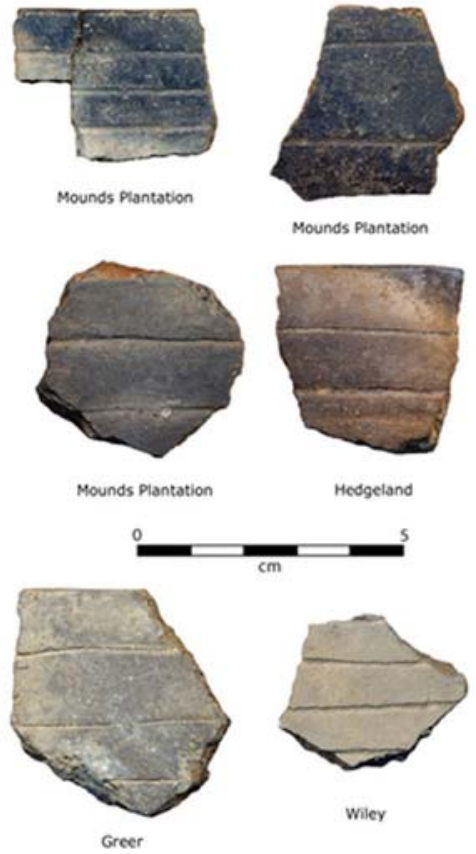

Wiley

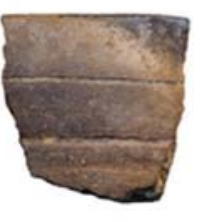

hodgetand

Figure 2. Examples of Coles Creek variety Coles Creek and variety Greenhouse used in the petrographic study.

\section{Methodology}

The petrographic analysis was conducted by Leslie Cecil at Stephen F. Austin State University. The 50 samples were sent to Spectrum Petrographics where they were cut with a wet saw and embedded in an epoxy block. Petrographic analysis allows the analyst to identify minerals that are present in the clay pastes of different pottery vessels. Petrography allows analysis of many clay materials and inclusions at one time. One can study "the clay itself, natural inclusions in the clay, purposefully added inclusions, and glazes or slips on the clay surface" (Childs 1989:24). In order to conduct a petrographic analysis of pottery sherds/vessels, one must take a sample of the pottery to be analyzed and sand it down to a width of .03 microns (thin-sectioning. This allows the analysts to determine the kinds of minerals present based on the known optical principles of minerals seen through a polarizing microscope.

Thin-sectioning provides one objective means of classifying pottery pastes through the analysis of mineral size, shape, roundness, and frequency. Mineral size, shape, and roundness are established through a comparison of various graphs and tables (Shackley 1975:44-51). The most common geological method 
of determining the quantity of minerals in a thin section is point counting. Point counting determines the number of different minerals along a predetermined area (for example, $10 \mathrm{~mm}$ ) of the length and width of the section (Chayes 1956). Various studies have employed different methods for counting the frequency of inclusions: Peacock (1973) uses a random grain selection; Middleton, Freestone, and Leese (1985) use a variation of systematic sampling along linear transects with tests of accuracy for different thin-section samples; and Dickenson and Shutler (1979) use an area point count (all minerals, inclusions, and voids are counted in the field of view). Middleton et al. (1985) compared area counting to standard geological point counting and determined that the number of minerals counted was equal and the only difference was that area counting resulted in a smaller mean mineral diameter. Because mean diameter of minerals was not critical and Cecil obtained similar point counts with standard point counts and area point counts (tested on 10 sherds of different matrices), she implemented area counting for a field of view with 4X magnification (all thin section images were taken at $5 \mathrm{X}$ magnification-due to the $1 \mathrm{x}$ magnification of the digital camera and pole mount).

Although petrographic analysis is important to the research goals, there are some limitations. Thinsectioning may not produce the full mineralogical composition of a pottery sample due to sampling error and because the method of producing thin-section slides involves grinding and polishing of the sample (Orton et al. 1993). In addition to problems with sample preparation, petrographic analysis alone cannot determine the type of clay mineral in the sherd because of the refractive characteristics of clay minerals.

\section{Results}

Four paste variants (Sandy Paste, Sandy Paste with Grog, Sandy Paste with bimodal Quartz, and Sandy Paste with Iron) were detected. All samples had sandy pastes, with quartz sand ranging from 5 to 30 percent of the volume (10-20 percent for most sherds). Only one specimen was classified in the category of Sandy Paste without other materials.

The Sandy Paste with Grog paste group was subdivided because of inclusion variations. In addition to the differences in pastes, Cecil recognized two general clay paste categories: a dense, silty, homogenous clay fabric and a sandy, coarser sand clay fabric. These differences could be the result of use of both a silt-based clay and a sand-based clay and/or the potters sieving the clays to obtain different fabrics. In general, small quartz minerals, biotite, iron, and organics most likely occur because they were part of the clay body. They are also not too angular suggesting that they resulted from weathering from the parent material. K-feldspar in a few of the samples probably resulted from igneous rock that weathered into the clay bed. Obvious culturallyadded inclusions include angular, larger quartz particles, bone, and grog.

By far, the most numerous category (40 of the 50 samples) was Sandy Paste with grog (Figure 3). Variations within this group were identified however. Half of the samples contained simple quartz sand lacking other minerals. In all but two, the quartz particles were angular suggesting that either they were crushed during the processing of raw materials (most likely sandy clay) and included as temper, or they were natural inclusions in sandy clays from upland contexts. It was noted that several samples had distinctly silty pastes; most of these were from Hedgeland, Wiley, and Alphenia Landing_all located in the Lower Mississippi Valley. However, a few samples from Mounds Plantation and the Colbert and Greer sites also had silty pastes. The silty clays also tended to have high birefringence colors suggesting that they were weathered from a mica-rich parent material.

Two specimens, both from central Louisiana, have distinctly rounded quartz particles indicating that that they are extensively weathered (Figure 4). It is likely that potters were intentionally selecting river sand to add to the clay paste for tempering. If the quartz was not a cultural addition, it came from clay in an alluvial setting. 


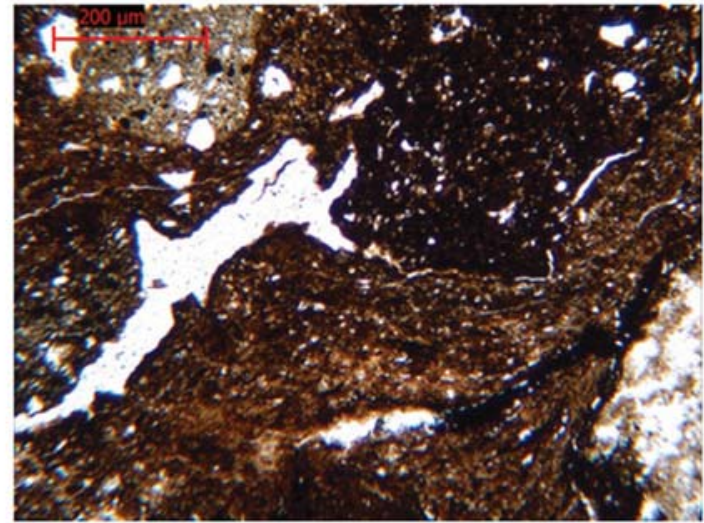

Mounds Plantation

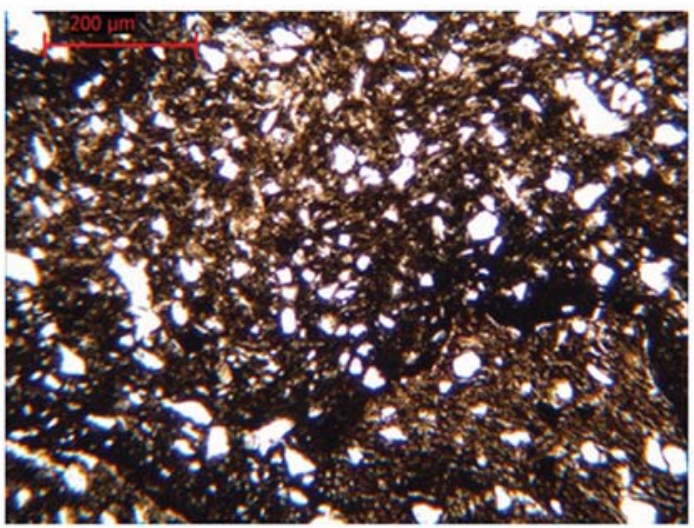

Greer

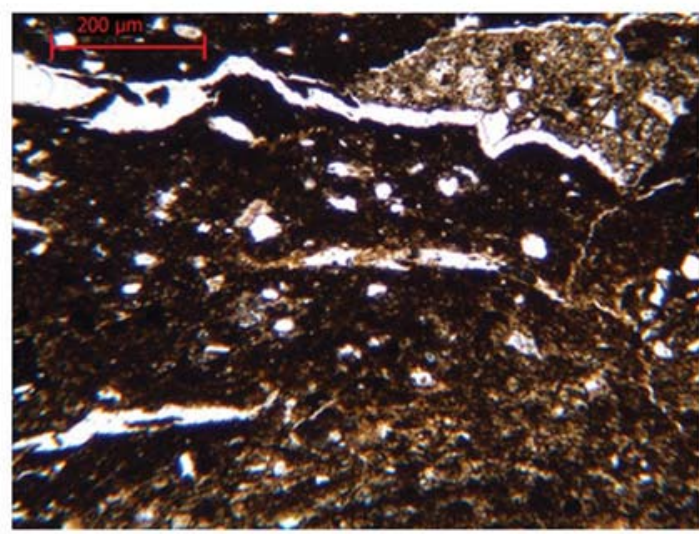

Wiley

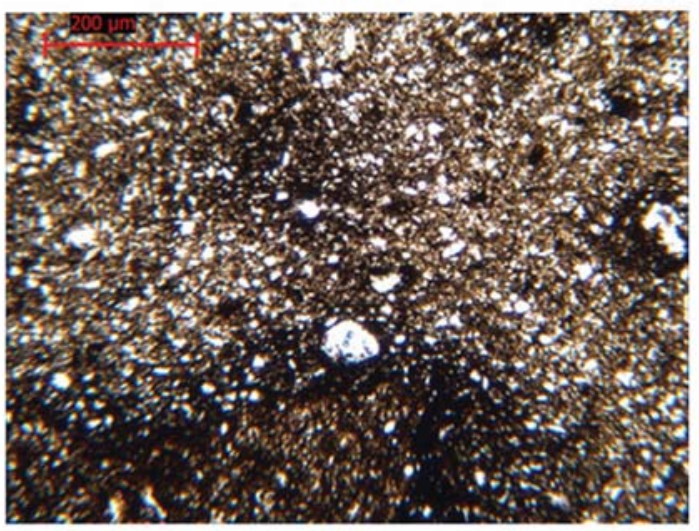

Crawford

Figure 3. Thin sections of selected sherds with sandy paste and grog only (plane, polarized light, 5x magnification).

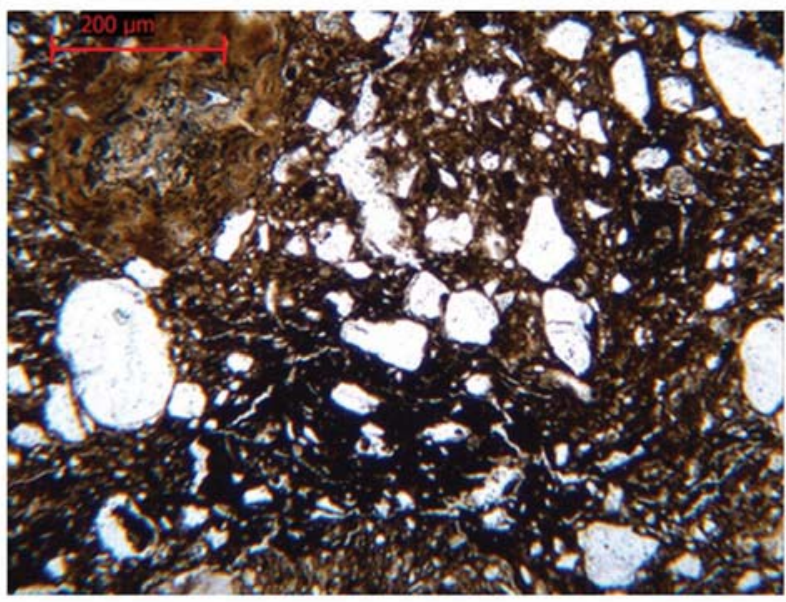

Chevalier

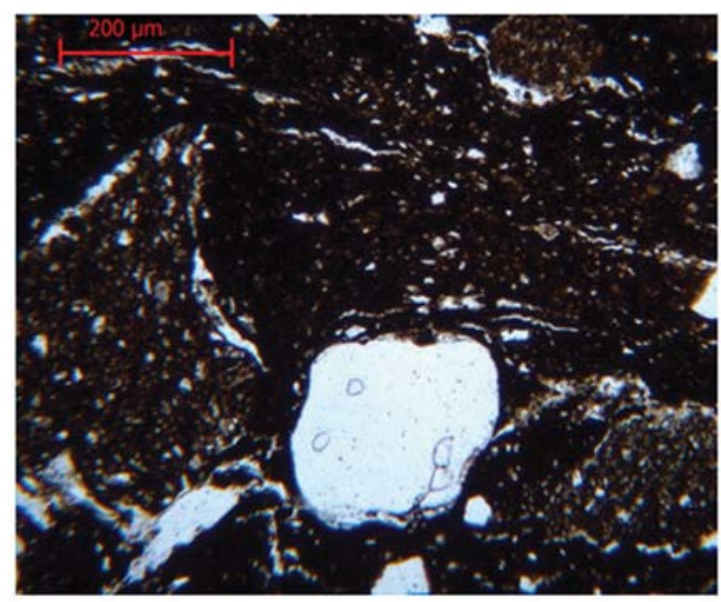

Crawford

Figure 4. Thin sections of selected sherds with sandy paste, grog and rounded quartz (plane, polarized light, $5 \mathrm{x}$ magnification). 
Seven samples contained grog and chert (Figure 5). The chert likely was part of sand intentionally added as temper. All of these samples had sandy rather than silty pastes. Five samples had grog with biotite. Not surprisingly, the clays of these sherds have high birefringence colors suggesting that the parent material may be mica related. Three samples have both chert and biotite, and one specimen, from Mounds Plantation, has chert, biotite, and potassium feldspar. Because the potassium feldspar inclusions are angular and fairly large in size, it is likely that these minerals were included in the sand in the clay and crushed during the processing of the clay before pottery manufacture.

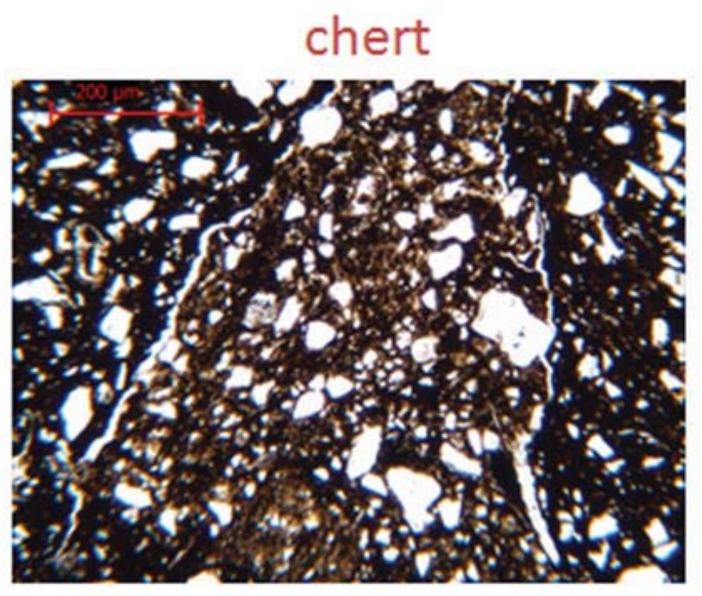

Pritchard's Landing

chert, and biotite

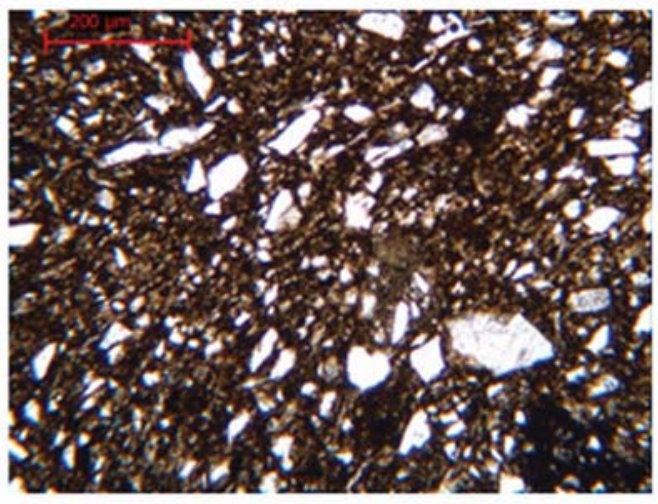

Mounds Plantation

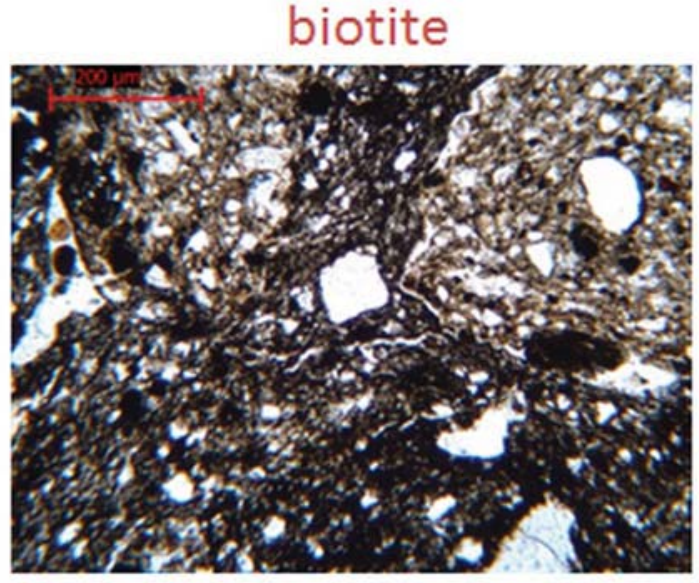

Pace
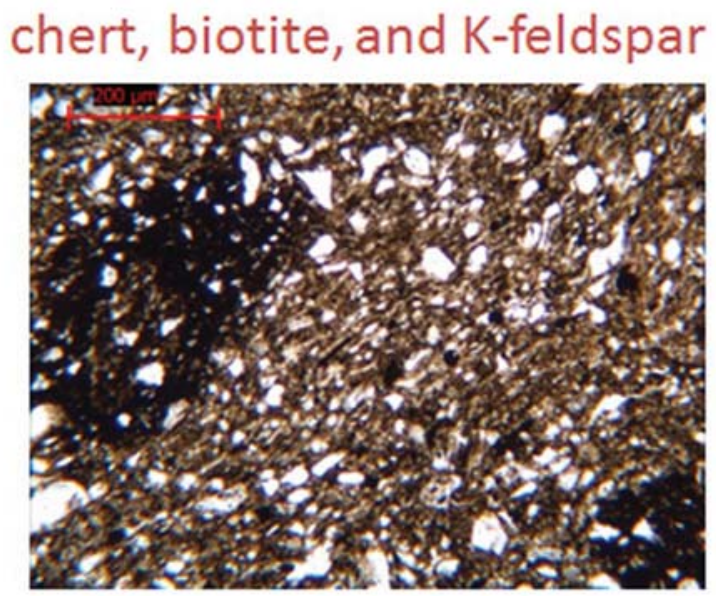

Mounds Plantation

Figure 5. Thin sections of selected sherds with sandy paste, grog and other minerals (plane, polarized light, $5 \mathrm{x}$ magnification).

Three sherds have the usual combination of sandy paste and grog, but also have crushed bone inclusions (Figure 6). All are from the Caddo Area. Interestingly, it is only in this subgroup that the grog also includes both bone and quartz. The sample from the Mounds Plantation site has five different kinds of grog in the sherd paste (the greatest variety detected in this analysis). 


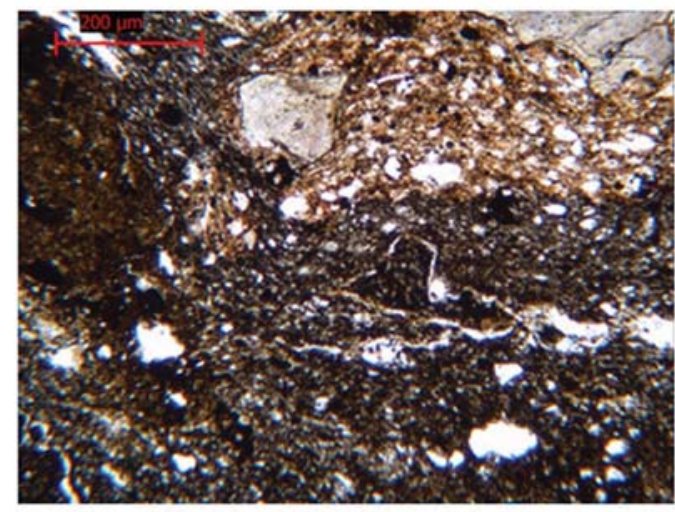

Mounds Plantation

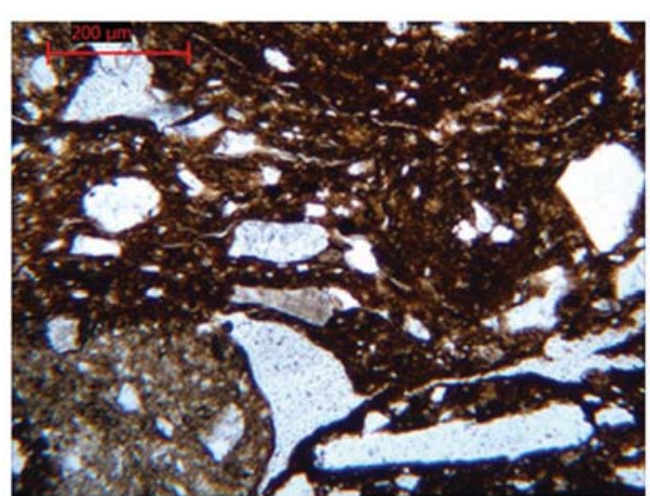

Gahagan

Figure 6. Thin sections of selected sherds with sandy paste and bone (plane, polarized light, 5x magnification).

Another paste group was distinguished by the presence of bi-modal (large and small) quartz and other inclusions (Figure 7). Eight specimens had these characteristics. The fine quartz that is less angular resulted from weathering into or with the clay, and the larger angular quartz likely is temper. Thus, the angular quartz may have resulted from crushing the sandy clay needed for pottery manufacture.

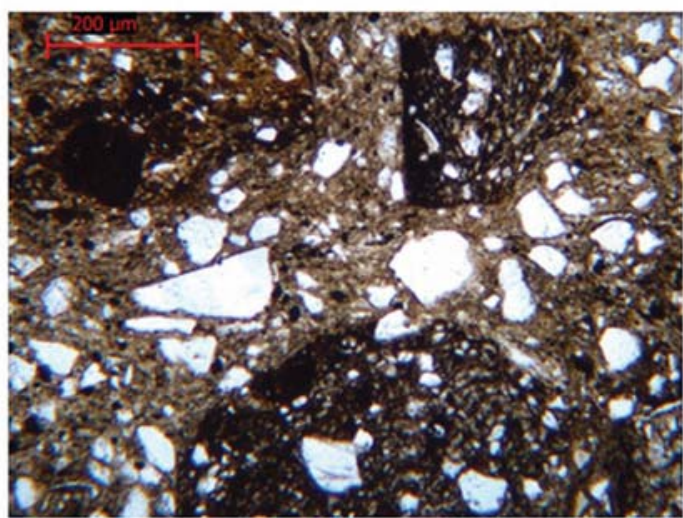

Pace

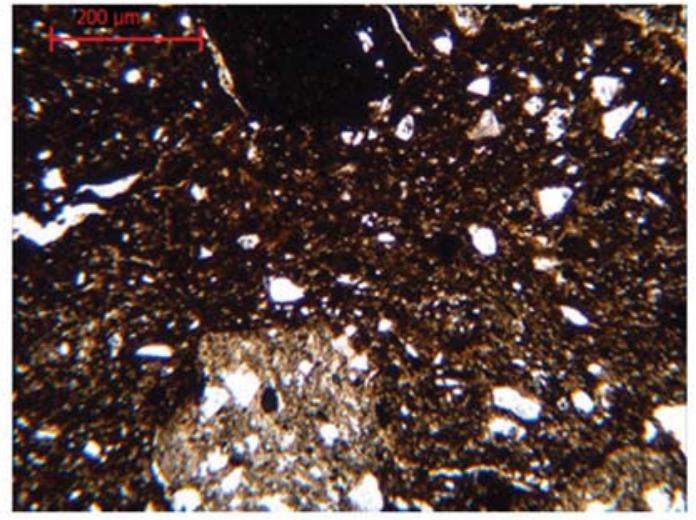

Smithport Landing

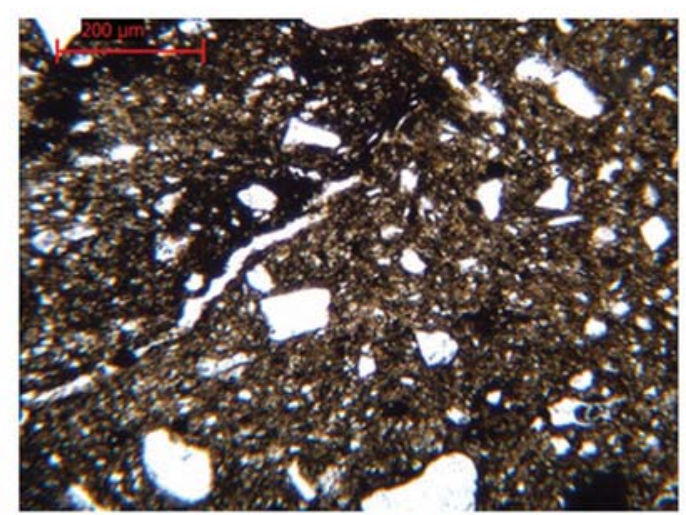

Clear Creek Bay

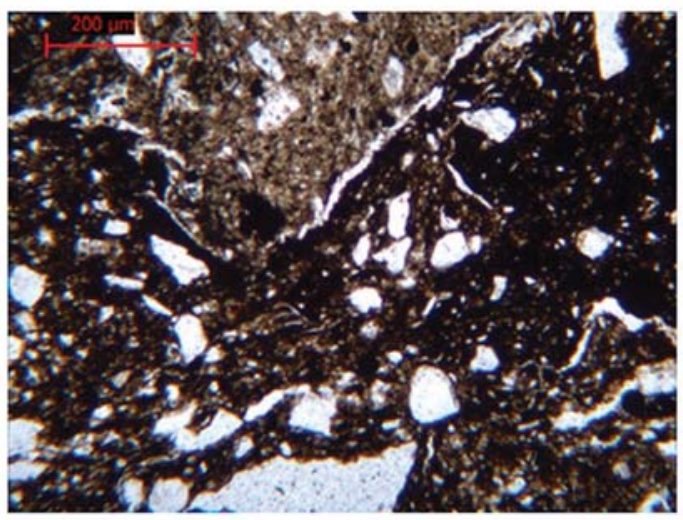

Greer

Figure 7. Thin sections of selected sherds with sandy paste and bi-modal quartz (plane, polarized light, $5 \mathrm{x}$ magnification). 
Finally, one sample from the Crawford Site had no grog, but did include crushed iron ore particles in addition to quartz sand (Figure 8). The presence of iron is most likely due to a high iron content clay (the ribbons of iron suggest that the clay was iron-rich and the iron is not a cultural inclusion).

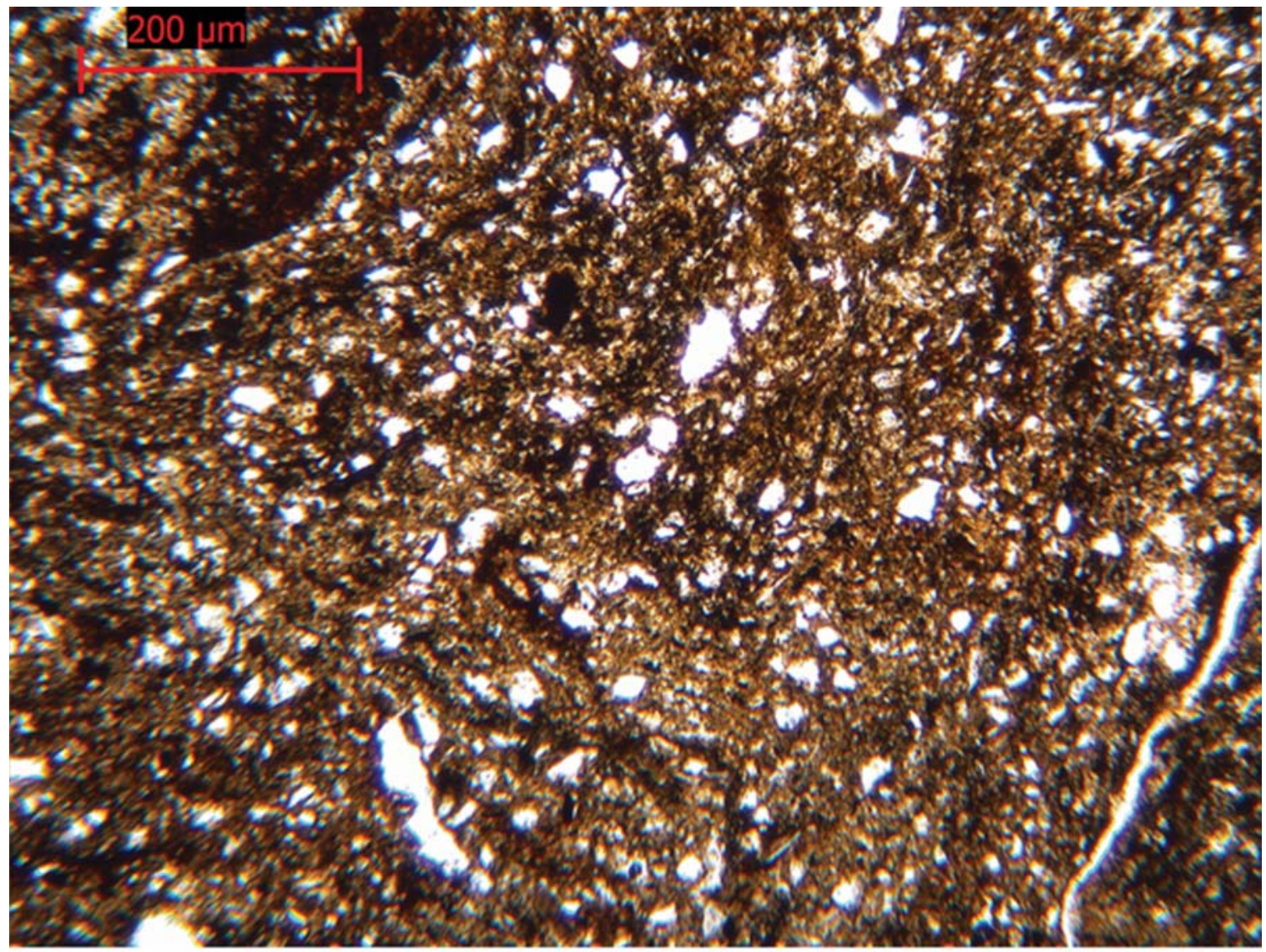

\section{Crawford}

Figure 8. Thin section of sherd with sandy paste and iron (plane, polarized light, 5x magnification).

\section{Discussion}

Figure 9 is a graphic representation of the various paste groups as defined by Cecil. The chart shows that the simple combination of grog with a sandy paste (represented by the blue color) occurs throughout the regions, but is more dominant in the samples to the east. The overall impression, however, is that considerable diversity exists within the regions, indeed, even within individual sites for which multiple samples were examined. For example, we used ten samples from Mounds Plantation and, as evident in the chart, there was much variety in the paste groups represented. Comparisons between regions will be tentative until we obtain a better idea of variation within regions.

That said, there are a some general differences between the Caddo Area and Lower Mississippi Valley that can be discerned by simplifying the original paste categories. The trends correspond well with our existing knowledge of ceramic technologies and regional geologies. 


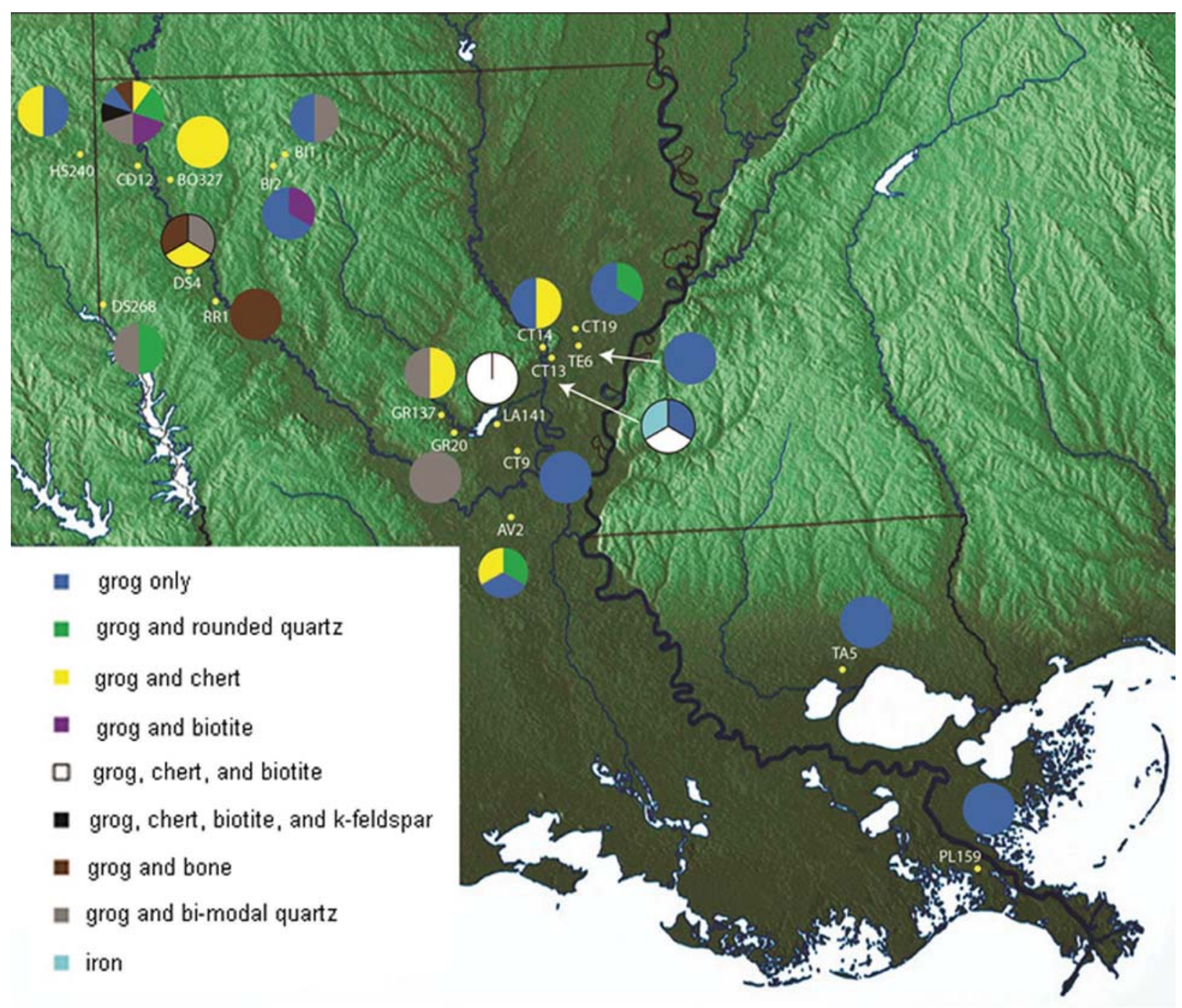

Figure 9. Distribution of paste categories in sampled sites.

Figure 10 shows percentages of samples by paste category for each region. The upper three paste categories are better represented in the Lower Mississippi Valley relative to the Caddo area; the lower three display the opposite tendency. The presence of minerals other than quartz occurs most frequently in the Caddo area. This tendency might be due to the use of clays from upland drainages and Tertiary marine deposits in the immediately surrounding uplands of northwest Louisiana.

The deliberate addition of sand as temper as suggested by the specimens with bi-modal quartz also is more common in the Caddo Area, as is the use of crushed bone as temper. The use of bone temper has long been recognized as a common trait in the Caddo area, a characteristic that extends back into the Woodland period indicating considerable local temporal continuity in ceramic technology.

The silty nature of many samples from the Lower Mississippi Valley was noted earlier. We do not know whether this is a natural characteristic of the clays, or related to preparation methods in the Lower Mississippi Valley that involved removal of coarse sand particles. However, these characteristics might be responsible for the traditional impression that pottery from the Caddo area is more "coarse." 


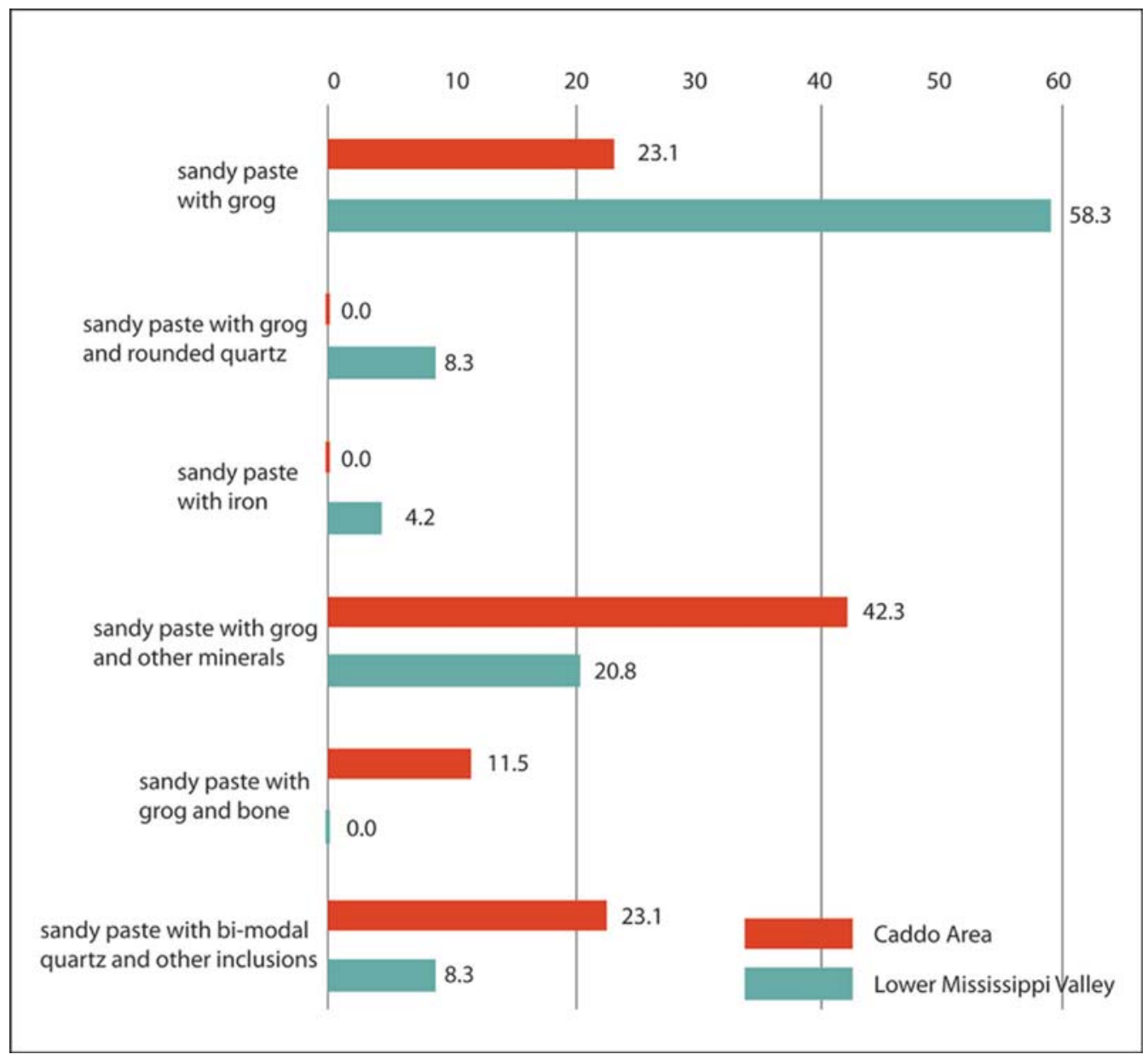

Figure 10. Regional differences in paste categories.

Despite this impression, the amount of sand as measured by number of quartz particles per sample is greater in the Lower Mississippi Valley samples, as are numbers of voids (Table 1). Grog inclusions tend to be slightly more prevalent in the Caddo Area samples. The standard deviations on these statistics are so high however, that we cannot conclude that any clear patterns are present.

\begin{tabular}{|l|c|c|c|}
\cline { 2 - 4 } \multicolumn{1}{c|}{} & Quartz & Grog $^{\mathbf{1}}$ & Voids \\
\hline Caddo Area & 1180.5 & 32.8 & 132.2 \\
\hline Lower Mississippi Valley & 1833.8 & 24.7 & 143.6 \\
\hline
\end{tabular}

Table 1. Number of inclusions in thin sections by region

${ }^{1}$ The grog counts for this study do not reflect the volume that the grog occupies in the sherd. While the counts may represent 2-3 percent of all counted inclusions, by volume, the grog inclusions represent approximately 25 percent of the paste. Most grog inclusions measured over $2 \mathrm{~mm}$ in size.

The two varieties appear to have temporal significance (var. Coles Creek seems to occur earlier than var. Greenhouse in the Lower Mississippi Valley) and thus, differences between them might be useful for identifying technological trends. However, because samples for the two varieties were uneven between the regions in this study, it is difficult to assess if they differ in terms of the paste categories (Figure 11). A larger sample of var. Greenhouse sherds is needed from the Lower Mississippi Valley sites. 


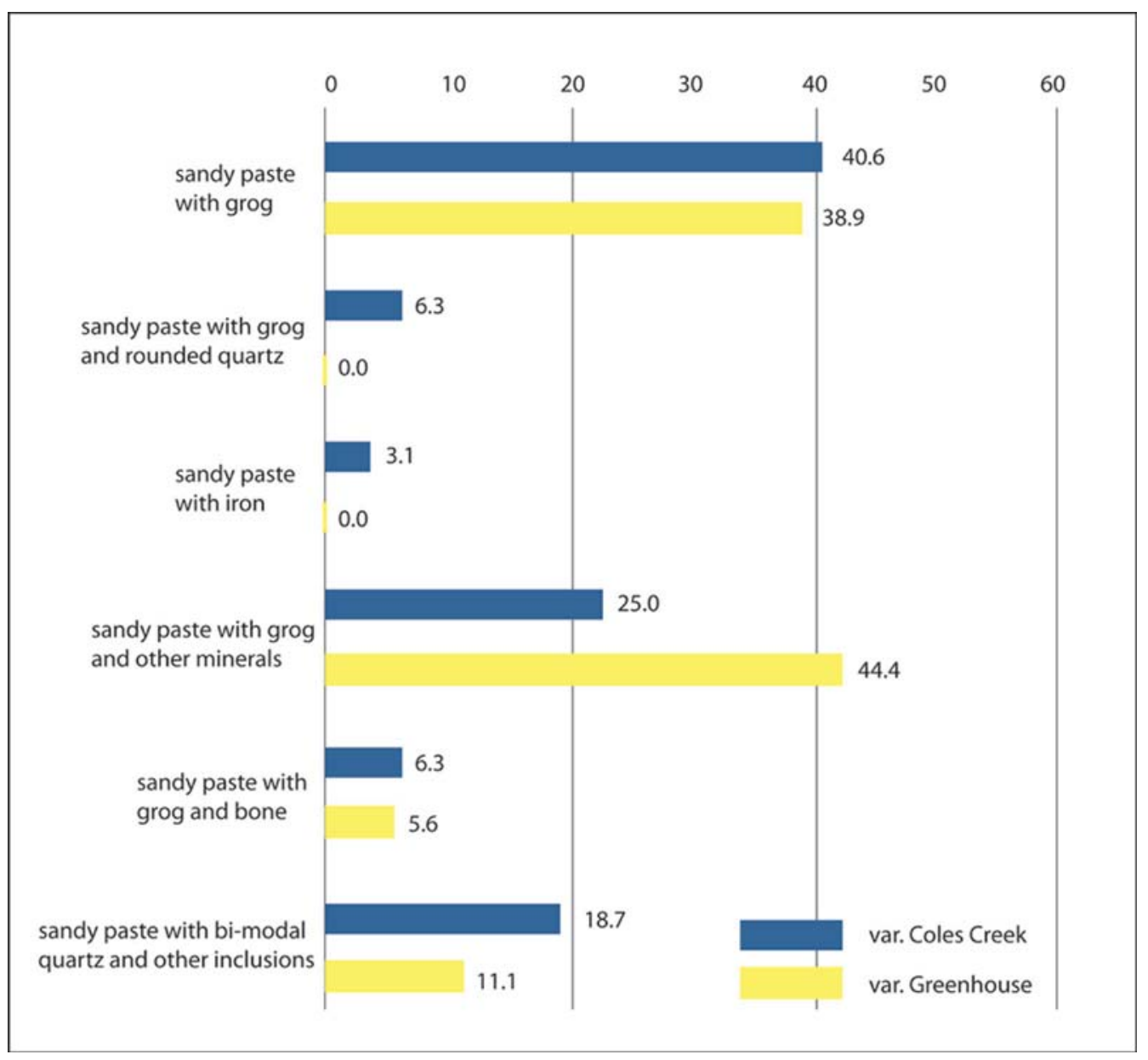

Figure 11. Paste categories for vars. Coles Creek and Greenhouse.

The samples that we utilized as representing the Lower Mississippi Valley came from sites in central Louisiana, a culturally dynamic region during the Coles Creek period that was in close proximity to the Red River sites sampled in the Caddo area. If pottery technologies, or actual pots, were conveyed between early Caddo and Coles Creek societies, central and northwest Louisiana are likely to have been regions of primary importance in this interaction. This study suggests that it is unlikely that the Coles Creek pottery in the Caddo Area resulted from Lower Mississippi Valley immigrants who either brought ceramic vessels with them, or who rigorously maintained their traditional pottery manufacturing technologies. Population movement between the two areas might have taken place, but most pots were made locally and traditionally distinct technologies were maintained. The diversity of paste characteristics at sites such as Mounds Plantation, a particularly large settlement that eventually developed into a ceremonial center during the late eleventh century, suggests that a few places might have served as nodes of interaction. Greater differences between the regions might be seen through comparison of smaller, strictly residential contexts.

We suspect that samples from sites farther east, such as the Natchez Bluffs region and upper Tensas and Yazoo Basins, also would exhibit even sharper differences with those from the Caddo Area, both because of their greater geographical distance and because utilized clays are less likely to be derived from or influenced by the Tertiary uplands of northwest Louisiana.

In conclusion, although there does not appear to be a sharp dichotomy in paste characteristics that enables us to differentiate pottery between the Caddo and central Louisiana Coles Creek areas into sortable types, variation across space can be discerned through detailed paste analysis as demonstrated here. We need additional studies from broader geographical regions and more diverse site types. 


\section{Acknowledgements}

We would like to thank the following people and institutions who provided samples for the study: Dr. Pete Gregory, Williamson Museum, Northwestern State University; Dr. Rebecca Saunders, Louisiana Museum of Natural History, Louisiana State University; Ms. Ashley Fedoroff, Collections Manager, Louisiana Division of Archaeology. Thanks also to two reviewers who provided helpful comments. The research that is the subject of this paper was conducted through the State of Louisiana's Regional Archaeology Program based at Northwestern State University of Louisiana. It has been financed with state funds and with federal funds from the National Park Service, U.S. Department of the Interior.

\section{References Cited}

Chayes, Felix

1956 Petrographic Modal Analysis. John Wiley, New York.

Childs, S. Terry

1989 Petrographic Analysis of Archaeological Ceramics. Material Research Science 25:24-29.

Dickenson, William R., and Richard Shutler, Jr.

1979 Petrography of Sand Tempers in Pacific Island Potsherds. Geological Society of America Bulletin, Part II 90:1644-1701.

Ford, James A.

1951 Greenhouse: A Troyville-Coles Creek Period Site in Avoyelles Parish, Louisiana. Anthropological Papers of the American Museum of Natural History Volume 44, Part 3. American Museum of Natural History, New York.

Girard, Jeffrey S., Timothy K. Perttula, and Mary Beth Trubitt

2014 Caddo Connections, Cultural Interactions Within and Beyond the Caddo World. Rowman and Littlefield, Lanham, Maryland.

Middlestone, Andrew P., Ian C. Freestone and Morven N. Lesse

1985 Textural Analysis of Ceramic Thin Sections: Evaluations of Grain Sampling Procedures. Archaeometry 27(1):64-74.

Newell, H. Perry and Alex D. Krieger

1949 The George C. Davis Site, Cherokee County, Texas. Memoir No. 5. Society for American Archaeology, Menasha, Wisconsin.

Orton, Clive, Paul Tyers, and Alan Vince

1993 Pottery in Archaeology. Cambridge University Press, Cambridge, England. Peacock, David

1973 The Black-Burnished Pottery Industry in Dorset. Research Reports Council for British Archaeology 10:63-65.

Phillips, Philip

1970 Archaeological Survey in the Lower Yazooo Basin, Mississippi 1949-1955, 2 vols. Papers of the Peabody Museum of American Archaeology and Ethnology 60. Harvard University, Cambridge, Massachusetts.

Shackley, Myra L.

1975 Archaeological Sediments: A Survey of Analytical Methods. John Wiley, New York. 